\title{
Migration and Aggregation Behavior of Nickel and Iron in Low Grade Laterite Ore with New Additives
}

\author{
Yuanbo Wang, Chaoqun Nie, Bo Li * and Yonggang Wei
}

Citation: Wang, Y.; Nie, C.; Li, B.; Wei, Y. Migration and Aggregation Behavior of Nickel and Iron in Low Grade Laterite Ore with New

Additives. Metals 2021, 11, 2033.

https://doi.org/10.3390/met11122033

Academic Editor: Mark E. Schlesinger

Received: 8 November 2021

Accepted: 9 December 2021

Published: 15 December 2021

Publisher's Note: MDPI stays neutral with regard to jurisdictional claims in published maps and institutional affiliations.

Copyright: (c) 2021 by the authors. Licensee MDPI, Basel, Switzerland. This article is an open access article distributed under the terms and conditions of the Creative Commons Attribution (CC BY) license (https:// creativecommons.org/licenses/by/ $4.0 /)$.

\begin{abstract}
Engineering Research Center of Metallurgical Energy Conservation and Emission Reduction, Ministry of Education, Kunming University of Science and Technology, Kunming 650093, China; 20192102016@stu.kust.edu.cn (Y.W.); 20202128006@stu.kust.edu.cn (C.N.); weiygcp@kust.edu.cn (Y.W.) * Correspondence: 20202228006@stu.kust.edu.cn; Tel.: +86-15987127468
\end{abstract}

\begin{abstract}
This study focused on the preparation of high-grade ferronickel concentrate, the behavior of efficient migration and the polymerization of ferronickel particles during reduction roasting, by adding calcium fluoride and a ferronickel concentrate to low-grade laterite ore from Yunnan. The effects of temperature, holding time, reductant content, ferronickel concentrate content and magnetic field intensity on the preparation of the ferronickel concentrate were studied and the optimum conditions were determined as follows: $30 \%$ ferronickel concentrate (metal Ni-4.68\%, metal $\mathrm{Fe}-45.0 \%$ ), $8 \%$ coal, $7 \%$ calcium fluoride, reduction temperature of $1250{ }^{\circ} \mathrm{C}$, reduction time of $60 \mathrm{~min}$ and the intensity of magnetic separation is $150 \mathrm{mT}$. The proportion of nickel and iron in ferronickel concentrate was $88.7 \%$ (metal Ni-8.62\%, metal Fe-80.1\%), and the recovery efficiency of nickel and iron are $98.8 \%$ and $82.4 \%$, respectively. X-ray diffraction and scanning electron microscopy indicated that ferronickel-concentrate, as an activating agent, improved the aggregation effect of ferronickel particles. The efficient migration and polymerization of ferronickel particles in the ore significantly increased the size of the ferronickel particles with additives, therefore a high-grade ferronickel concentrate was prepared, and the reduction and recovery efficiency of laterite nickel ore was improved.
\end{abstract}

Keywords: low grade laterite ore; ferronickel concentrate; magnetic separation; additives; migration and aggregation

\section{Introduction}

Nickel is an important strategic reserve metal and plays an extremely important role in the development of the national economy [1]. The consumption of nickel resources in China ranks first in the world, but the shortage of nickel resources has become increasingly problematic. With the rapid development of the stainless-steel industry, the demand for nickel is increasing [2]. The nickel used to produce stainless steel accounts for about $65 \%$ of global nickel production. In order to cope with the present situation of high cost in stainless steel production, it has become important to develop and utilize laterite nickel ore, and produce low-cost ferronickel raw materials [3]. With the depletion of high-grade nickel sulfide ore, low-grade laterite nickel ore has gradually become the main raw material for the nickel extraction [4-7].

Laterite nickel ore is an important nickel mineral resource, which has the characteristics of large reserves, low-grade and difficult extraction behavior. In total, $70 \%$ of the laterite nickel resources in China are distributed in Yuanjiang, Yunnan Province. The nickel laterite ore was mainly comprised of lizardite, revealing the sandwich-like morphology and quartz of irregular hexagonal granular structure, characterizing it as a complex ore. The contents of silicon dioxide and magnesium oxide in the ore are high, therefore it is considered as the typical garnierite. As discussed in the literature, reduction-roasting magnetic separation process, used for various types of laterite nickel ore has the advantages of short process, friendly environment and no pollution [8-10]. 
However, the experimental results show that the process has a low recovery efficiency of nickel and iron. Some researchers have studied the effect of accelerators on the reduction and polymerization of nickel and iron in the reduction of the roasting process of laterite nickel ore. Mainly sulfur-containing additives and sodium salt additives [11,12] have obvious effects on ferronickel recovery.

Zhou et al. $[13,14]$ studied the effect of $\mathrm{NaCl}$ addition on nickel minerals in reductive roasted laterite. After adding $\mathrm{NaCl}$, nickel and iron in raw ore aggregated efficiently to form ferronickel alloy particles. When the roasting time was prolonged, ferronickel alloy particles were separated from serpentine, thus nickel and iron were effectively enriched in the magnetic separation process. When $10 \% \mathrm{NaCl}$ and $8 \%$ anthracite were added into the raw ore, the reduction process was conducted out at roasting temperature of $1200{ }^{\circ} \mathrm{C}$ for $20 \mathrm{~min}$, followed by $150 \mathrm{mT}$ magnetic separation. The grades of nickel and iron were $7.09 \%$ and $67.9 \%$, which are relatively low. The recovery efficiency of nickel and iron were $98.3 \%, 72.1 \%$, respectively. In this research, the grades of nickel and iron were $8.62 \%, 80.1 \%$. Additionally, the recovery efficiency of nickel and iron are $98.8 \%, 82.4 \%$.

Some researchers showed that the utilization of approximately $10 \%$ wt $\mathrm{Na}_{2} \mathrm{~S}_{2} \mathrm{O}_{3}$ or S, resulted in a product with about $5-14 \% \mathrm{Ni}$ content and above $90 \%$ recovery. When the nickel and iron grades of raw ore are high, the nickel and iron grades in nickel iron concentrate are high. Both $\mathrm{Na}_{2} \mathrm{~S}_{2} \mathrm{O}_{3}$ and natural sulfur additives assisted the transformation of ore mineralogy and confirm the formation of ferronickel. Additionally, the effect of sulfur on the phase transformation has been studied carefully in the process of high-temperature reduction roasting of laterite minerals. The results showed that the addition of elemental $S$ can inhibit the formation of forsterite in the silica-magnesium laterite nickel ore, and that melted Fe-FeS eutectic is conducive to mass transfer, which promotes the migration and polymerization of ferronickel and causes the particles of ferronickel to aggregate into larger particles. For the laterite nickel ore, sulfur can lead to the formation of FeS and Fe-Ni at $500{ }^{\circ} \mathrm{C}$, thus achieving the selective separation of nickel and iron [15-17]. The addition of ferronickel concentrate has a similar function. Additionally, it further enhances the aggregation of metal nickel and iron. The ferronickel concentrate is added into low-grade laterite nickel ore as a nucleating agent, and, at the same time, a reductant and accelerator are added in the reduction-roasting process. The fine ferronickel particles that have been reduced are nucleated to nickel-iron zone under the action of interfacial energy.

The migration and enrichment of nickel and iron in the field can improve the growth of ferronickel particles, which is conducive to magnetic separation and can further improve the recovery efficiency of nickel and iron [18-20]. The extraction of nickel and iron from low-grade laterite nickel ore presents some issues, therefore, a new method of preparing ferronickel concentrate from low-grade laterite nickel ore is proposed in this paper. The objectives of this work were to obtain high-grade ferronickel concentrate, and the migration and aggregation behavior of ferronickel under the influence of additives.

\section{Materials and Methods}

\subsection{Material}

\subsubsection{Laterite Ore}

In this study, laterite nickel ore from Yunnan Province was used as the raw material. The main components of laterite nickel ore were analyzed through chemical analysis. The phase composition of the laterite ore was analyzed using a X-ray diffractometer $\mathrm{Cu}-\mathrm{K} \alpha$ ray source, voltage of $35 \mathrm{kV}$, current of $20 \mathrm{~mA}$, scanning speed of $10^{\circ} / \mathrm{min}$, the diffraction angle

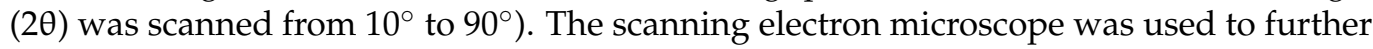
analyze the distribution of elements in the ore. TG/DSC (Netzsch Inc., Beijing, China) was used to determine the thermal properties of nickel laterite ore.

\subsubsection{Low-Grade Ferronickel Concentrate}

The ferronickel concentrate was obtained in the experiment by reduction laterite and magnetic separation laterite reduction products. Raw ore, calcium fluoride and anthracite 
are fully mixed and evenly packed into corundum crucible, and then reduced in a tubular furnace (GLS-1500X, Hefei kejing Material Technology Co., LTD, Beijing, China) for $60 \mathrm{~min}$ at $1250{ }^{\circ} \mathrm{C}$, and then wet-grinded for $12 \mathrm{~min}$. Finally, the ferronickel concentrate was separated by a magnetic separator (DTCXG-ZN50, Tangshan Dongtang Electric CO., LTD., Tangshan, China) under a magnetic field intensity of $150 \mathrm{mT}$. The main components of ferronickel concentrate were analyzed via chemical analysis (Chemical titration).

\subsection{Apparatus and Procedure}

At first, the ore was dried in a drying chamber, and then crushed to less than $0.25 \mathrm{~mm}$ in a vibration mill. Raw ore, reductant and concentrate were fully mixed and evenly packed into a corundum crucible, then placed in the constant temperature zone of the tubular furnace. The air in the tube of the furnace was discharged and the heating program was started. The sample was heated to the set temperature at a rate of $10{ }^{\circ} \mathrm{C} / \mathrm{min}$. In the reduction roasting process, $\mathrm{N}_{2}$ was used as a protective gas to prevent secondary oxidation of the sample. The sample was cooled in the furnace and removed from the furnace below $200{ }^{\circ} \mathrm{C}$. The reduced sample was taken out for wet grinding at around $12 \mathrm{~min}$, and the particle size of the sample was less than 74 microns, and then the ferronickel concentrate was separated using a magnetic separator. After liquid-solid separation, the concentrate and tailings were obtained. The concentrate was dried at $150{ }^{\circ} \mathrm{C}$, and the weight of the concentrate was measured. The flow-chart of the reduction-roasting magnetic separation experiment of laterite nickel ore are shown in Figure 1. The content of nickel and iron was analyzed, and the corresponding recovery efficiency was calculated. The specific experimental conditions and processes are shown in Figure 1. The recovery efficiency of $\mathrm{Ni}$ and Fe were calculated according to the following equation:

$$
X=\frac{m \times w}{M \times W+V \times Y} \times 100 \%
$$

where $X$ is the recovery efficiency of nickel or iron, $m$ is the weight of ferronickel concentrate, $w$ is the nickel or iron content in the ferronickel concentrate, $V$ is the weight of concentrate, $Y$ is the nickel or iron content in the concentrate, $M$ is the weight of raw ore, and $W$ is the nickel or iron content in the raw ore.

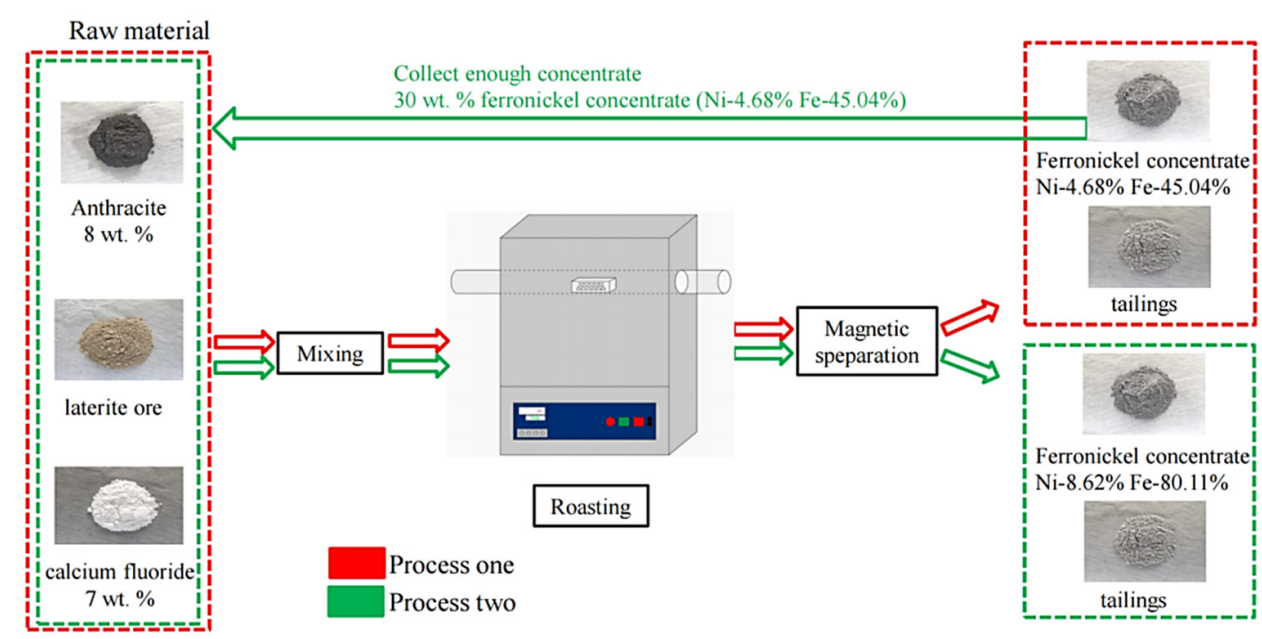

Figure 1. The flow chart of reduction roasting-magnetic separation experiment of laterite nickel ore.

The mineral phases were characterized by X-ray diffraction (Japan Science D/max-R diffractometer, Rigagu Inc., Beijing, China). To analyze and clarify the related mechanism, the microstructure of ferronickel concentrate in reduction product and the compositions of several spots in magnetic product were observed by scanning electron microscopy (SEM; HITACHI-S3400 N, Hitachi Inc., Tokyo, Japan).), equipped with energy dispersive X-ray spectroscopy (EDS, EDAX Inc., Beijing, China). 


\section{Results and Discussion}

\subsection{The Phase Composition of Samples}

The chemical analysis and XRD pattern of laterite ore is shown in Table 1 and Figure 2. The ore contained approximately $0.82 \mathrm{wt}$. \% of $\mathrm{Ni}$ and $9.67 \mathrm{wt}$. \% of Fe. The main phases included serpentine, silica and iron oxide. In Figure 3, the occurrence of Fe and O elements in the raw ore indicates that $\mathrm{Fe}$ in raw ore exists in the form of iron oxides. The distribution of $\mathrm{Mg}, \mathrm{Si}$ and $\mathrm{O}$ is highly consistent, and the aggregated particles are large, and is therefore considered as serpentine. The distribution of nickel elements is dispersive, but the relatively concentrated distribution of nickel elements in $\mathrm{Mg}$, $\mathrm{Si}$ and $\mathrm{O}$ regions can be clearly observed. The TG/DSC of laterite ore are shown in Figure 4. It is a typical silicon magnesium laterite ore. The nickel content is approximately $1 \%$ and the iron content is less than $20 \%[2,12,16,21]$.

Table 1. Chemical composition of the laterite ore sample.

\begin{tabular}{cccccccccc}
\hline Component & $\mathrm{Fe}$ & $\mathrm{Ni}$ & $\mathrm{Co}$ & $\mathrm{Al}_{2} \mathbf{O}_{3}$ & $\mathbf{M g O}$ & $\mathrm{CaO}$ & $\mathrm{SiO}_{2}$ & $\mathrm{Mn}$ & Others \\
\hline $\begin{array}{l}\text { Content } \\
\text { (wt. \%) }\end{array}$ & 9.67 & 0.820 & 0.0300 & 1.89 & 31.5 & 0.0300 & 37.4 & 0.0800 & 18.6 \\
\hline
\end{tabular}

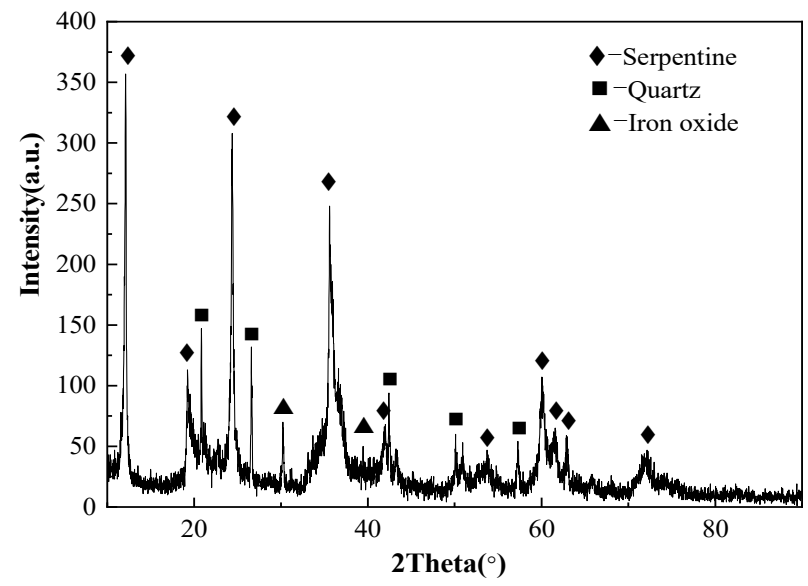

Figure 2. X-Ray Diffraction (XRD) analysis of laterite nickel ore.
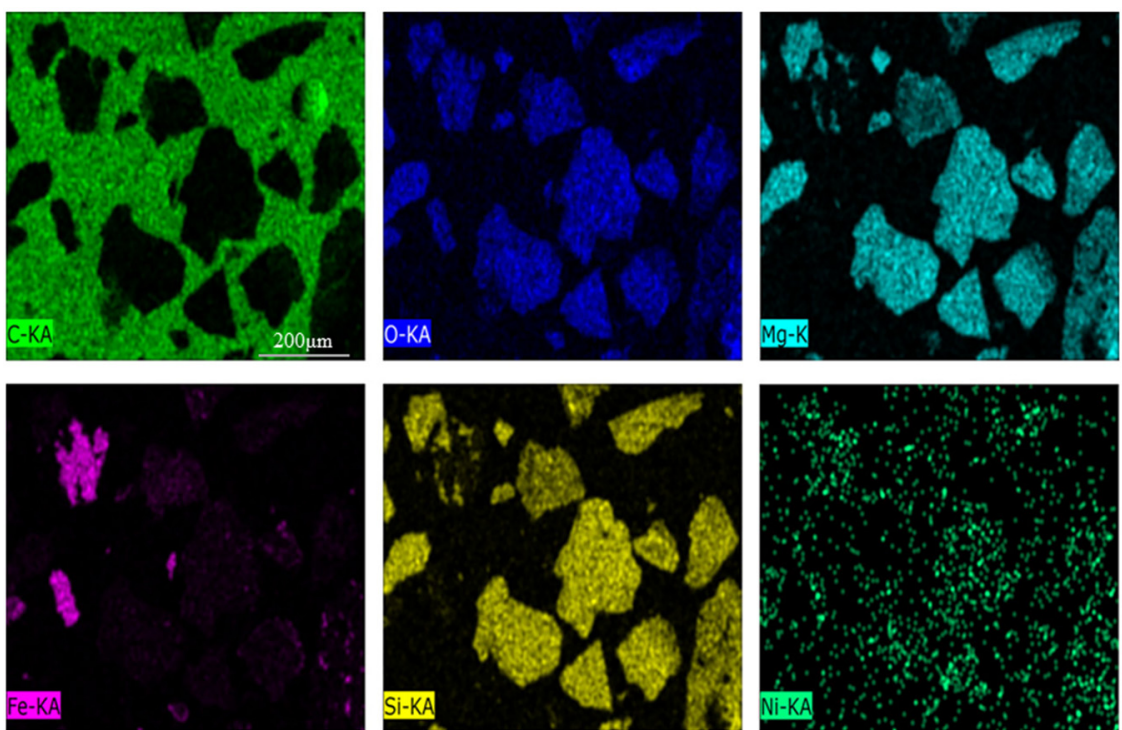

Figure 3. Scanning electron microscope of nickel laterite ore. 


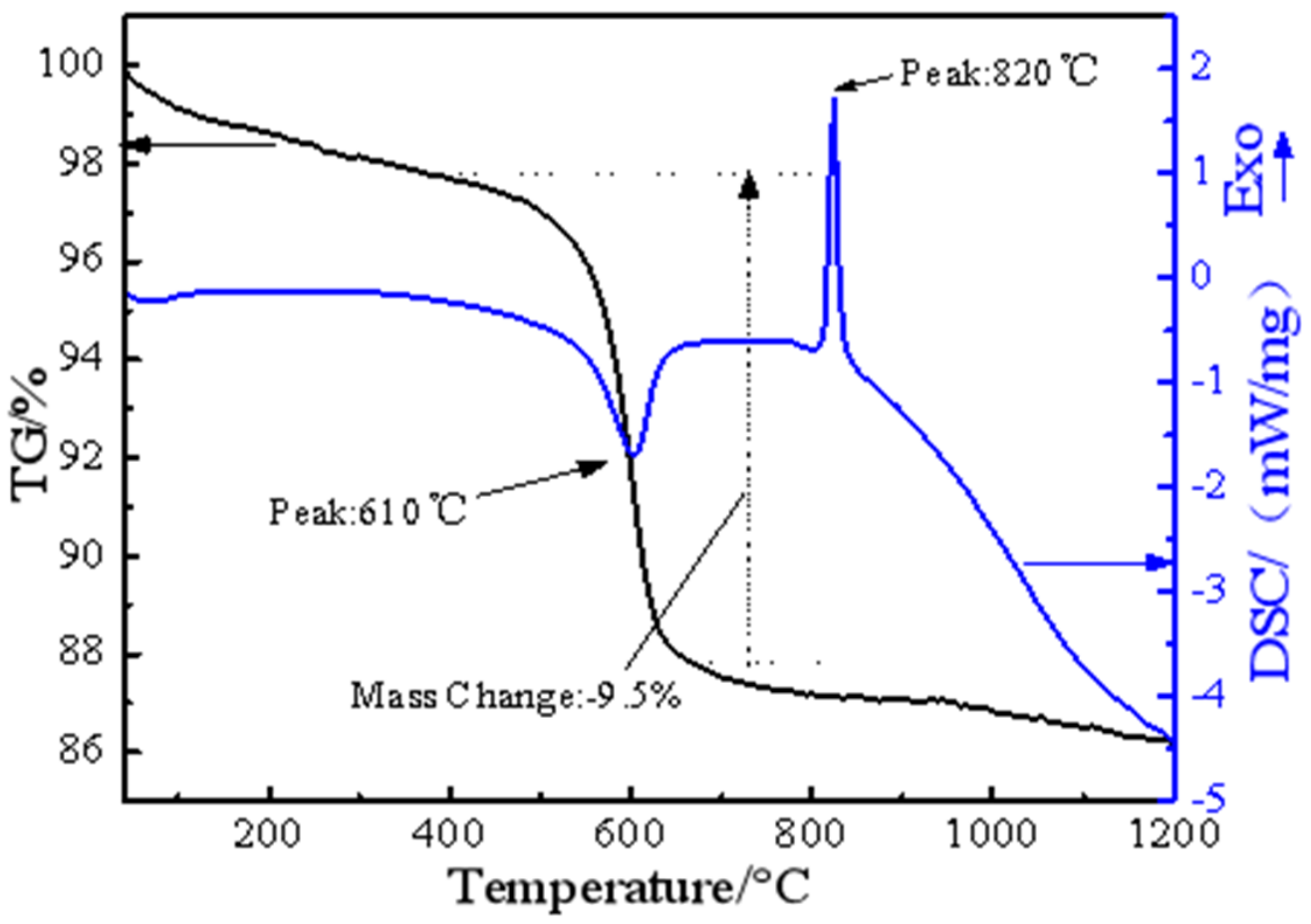

Figure 4. TG/DSC curves for thermal decomposition of the raw garnierite ore.

TG/DSC was used to determine the thermal properties of nickel laterite ore, as shown in Figure 4. It shows that the total weight-loss efficiency of the sample is around $12.7 \%$. As a result of the endothermic and exothermic processes, two main peaks were observed in the DSC thermogram. The first main peak at $610{ }^{\circ} \mathrm{C}$ is the result of removal of the chemically bound water from the ore. The dehydration process is an endothermic reaction, the sample quality decreases slightly, and no phase transition occurs. The second main peak at $820{ }^{\circ} \mathrm{C}$ is the result of serpentine phase change from amorphous material to olivine phase with good crystallinity [22,23]. This phase transition process is an exothermic reaction, which was verified by XRD in previous experiments.

The chemical analysis results of ferronickel concentrate are shown in Table 2 . The ferronickel concentrate contained approximately $4.68 \mathrm{wt}$. \% of $\mathrm{Ni}$ and $45.0 \mathrm{wt}$. \% of Fe.

Table 2. Chemical composition of the ferronickel concentrate.

\begin{tabular}{lcccccccc}
\hline Component & $\mathrm{Fe}$ & $\mathrm{Ni}$ & $\mathrm{Co}$ & $\mathrm{Al}_{2} \mathrm{O}_{3}$ & $\mathrm{MgO}$ & $\mathrm{CaO}$ & $\mathrm{SiO}_{2}$ & $\mathrm{Mn}$ \\
\hline $\begin{array}{l}\text { Content } \\
\text { (wt. \%) }\end{array}$ & 45.0 & 4.68 & 0.120 & 2.28 & 17.9 & 2.23 & 23.4 & 0.140 \\
\hline
\end{tabular}

Anthracite was used as the reducing agent. An industrial analysis of anthracite is shown in Table 3. The calcium fluoride used in the experiment is analytically pure.

Table 3. The composition of anthracite.

\begin{tabular}{ccccc}
\hline Properties & Fixed Carbon & Volatile Matter & Ash & Moisture \\
\hline Content (wt. \%) & 76.4 & 7.78 & 15.3 & 1.02 \\
\hline
\end{tabular}

\subsection{Reduction of Low-Grade Laterite Ore}

\subsubsection{Effects of Ferronickel Concentrate Dosage}

The effect of the ferronickel concentrate dosage on the reduction and magnetic separation of low-grade nickel laterite ore is shown in Figure 5. The experimental conditions 
were determined as follows: reduction temperature of $1250{ }^{\circ} \mathrm{C}$, roasting time of $60 \mathrm{~min}$, anthracite content of $8 \%$, calcium fluoride content of $7 \%$, magnetic separation intensity of $150 \mathrm{mT}$. As can be seen from Figure 5, when the concentrate dosage increased from 10\% to $50 \%$, the nickel grade increased from $5.35 \%$ to $6.82 \%$, and the recovery efficiency of the nickel increased from $96.8 \%$ to $98.3 \%$, then decreased to $93.3 \%$. The effect of concentrate on promoting the growth of ferronickel particles is not clear as the recovery efficiency of nickel decreases with the increase of the amount of ferronickel concentrate added. The grade and recovery efficiency of iron first increased and then decreased. The addition of concentrate can effectively reduce the content of silicon and magnesium. In addition, ferronickel concentrate, as an activating agent, can promote the growth of ferronickel grains, and effectively separate the ferronickel alloy from the sample reduced by a magnetic separation process, and improve the grade of nickel in the alloy. Given these results, the optimum dosage of concentrate is $30 \%$.

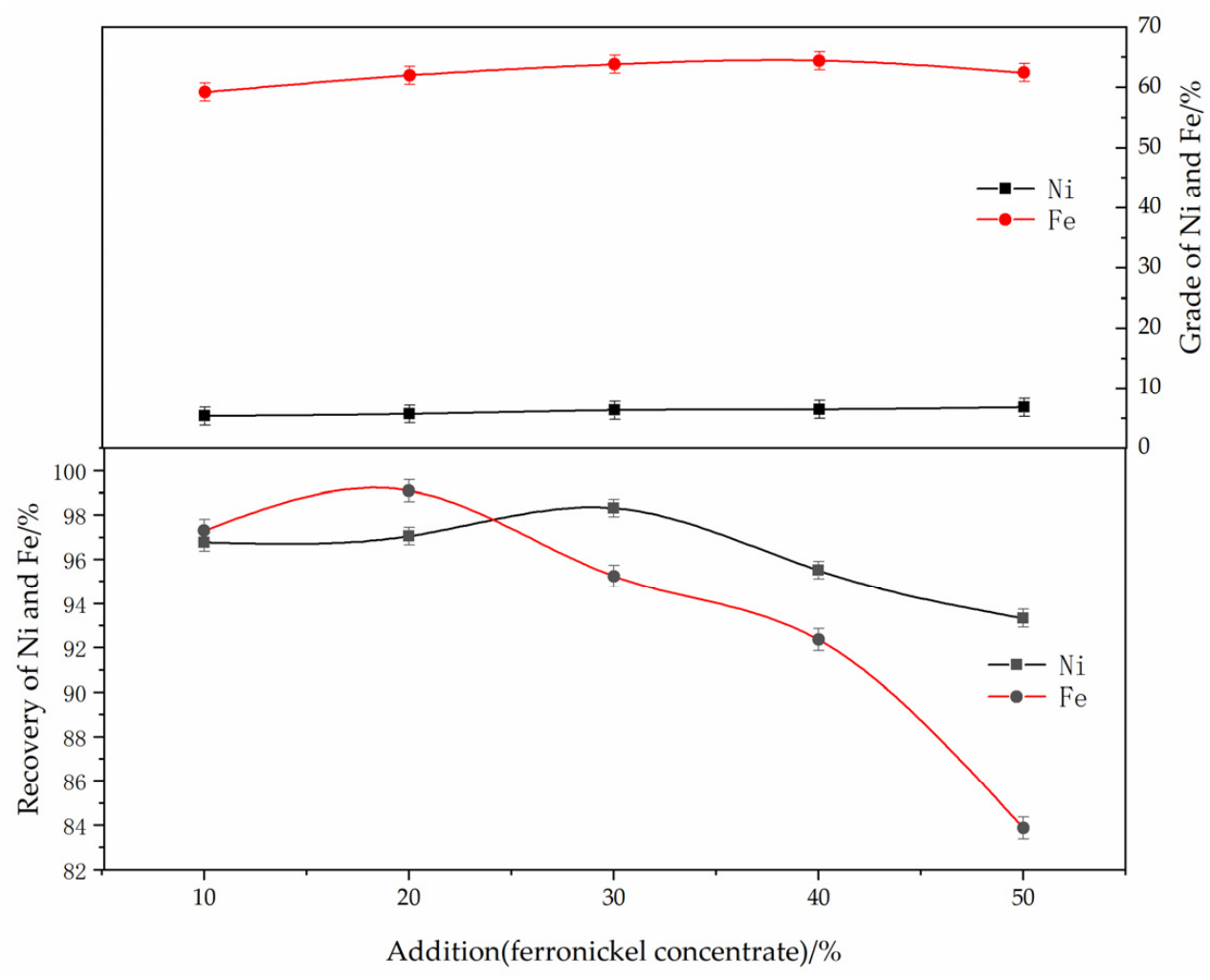

Figure 5. The effect of ferronickel concentrate dosage on the grade and recovery of nickel and iron. (The reducing temperature was $1250{ }^{\circ} \mathrm{C}$, the roasting duration was $60 \mathrm{~min}$, the reductant dosage was 8 wt. \%, the magnetic separation was $150 \mathrm{mT}$ ).

\subsubsection{Effects of Roasting Temperature}

The effect of roasting temperature on the reduction and magnetic separation of lowgrade nickel laterite ore is shown in Figure 6. The experimental conditions were determined as follows: ferronickel concentrate dosage of $30 \%$, roasting time of $60 \mathrm{~min}$, anthracite content of $8 \%$, calcium fluoride content of $7 \%$, and magnetic separation intensity of $150 \mathrm{mT}$. As can be seen from Figure 6, the reduction temperature has an obvious effect on the grade and recovery efficiency of iron and nickel. With an increase in the reduction temperature, the grades of nickel and iron clearly increase and then tend to become stable, while the recovery efficiency of iron and nickel increases and then decreases. When the temperature increased from 1100 to $1250^{\circ} \mathrm{C}$, the grade of nickel had no obvious change, but the grade of iron increased from $44.0 \%$ to $63.8 \%$, and the recovery efficiency of nickel and iron were $98.3 \%$ and $95.2 \%$, respectively. This indicates that the reduction efficiency increased with the increase in temperature and more nickel-iron oxides were reduced to metal nickel and 
iron. The recovery efficiency of nickel decreased to $88.38 \%$ when the temperature continued to rise to $1300{ }^{\circ} \mathrm{C}$. According to kinetics analysis, the metallization efficiency of nickel and iron was low at lower temperatures, and it was not conducive to the polymerization of ferronickel. When the temperature increased to $1250^{\circ} \mathrm{C}$, the recovery efficiency of nickel and iron showed a decreasing trend. This may suggest that the formation of iron olivine at this temperature affects the polymerization and growth of the ferronickel particle. A higher reduction temperature will cause material sintering, and hinder the reaction process and magnetic separation, resulting in lower nickel grade in concentrate. The results show that a suitable reduction temperature is conducive for improving the grades of iron and nickel. So, the optimum roasting temperature is $1250{ }^{\circ} \mathrm{C}$.

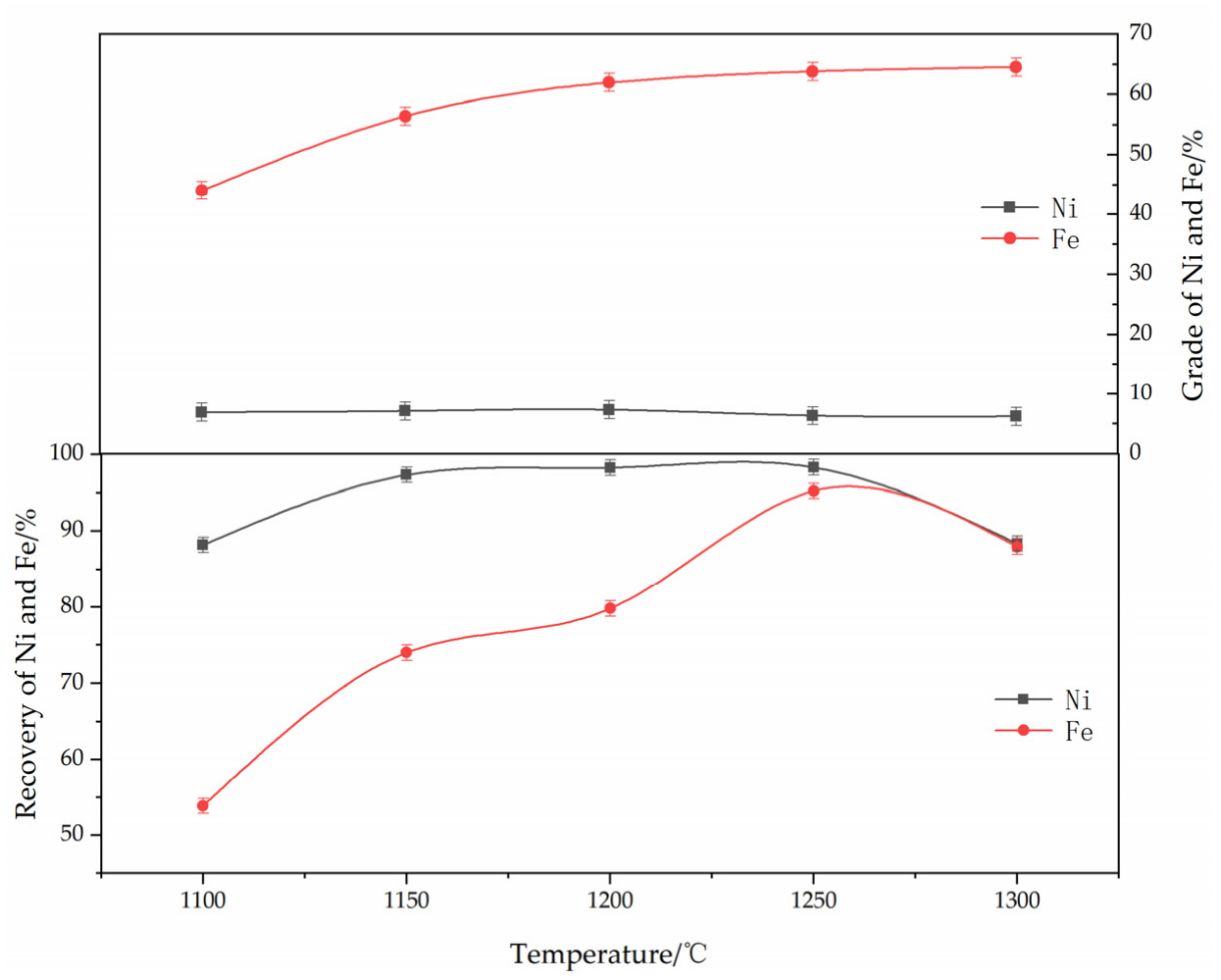

Figure 6. The effect of temperature on the grade and recovery of nickel and iron in ferronickel concentrate. (The ferronickel concentrate dosage was $30 \mathrm{wt}$. \%, the roasting duration was $60 \mathrm{~min}$, the reductant dosage was $8 \mathrm{wt}$. \%, the magnetic separation was $150 \mathrm{mT}$ ).

\subsubsection{Effects of Roasting Time}

The effect of the roasting time on the reduction and magnetic separation of low-grade nickel laterite ore is shown in Figure 7. The experimental conditions were determined as follows: ferronickel concentrate dosage of $30 \%$, reduction temperature of $1250{ }^{\circ} \mathrm{C}$, anthracite content of $8 \%$, calcium fluoride content of $7 \%$, and magnetic separation intensity of $150 \mathrm{mT}$. As can be seen from Figure 7, with the increase in the roasting time, the grades of nickel and iron first increased and then decreased. The grades of nickel and iron reached their peak at approximately $60 \mathrm{~min}$. With the increase in roasting time, more nickel oxides were reduced to nickel metal, which made the grade of nickel increase in the ferronickel concentrate. Considering the energy consumption, the optimum roasting time was found to be $60 \mathrm{~min}$. 


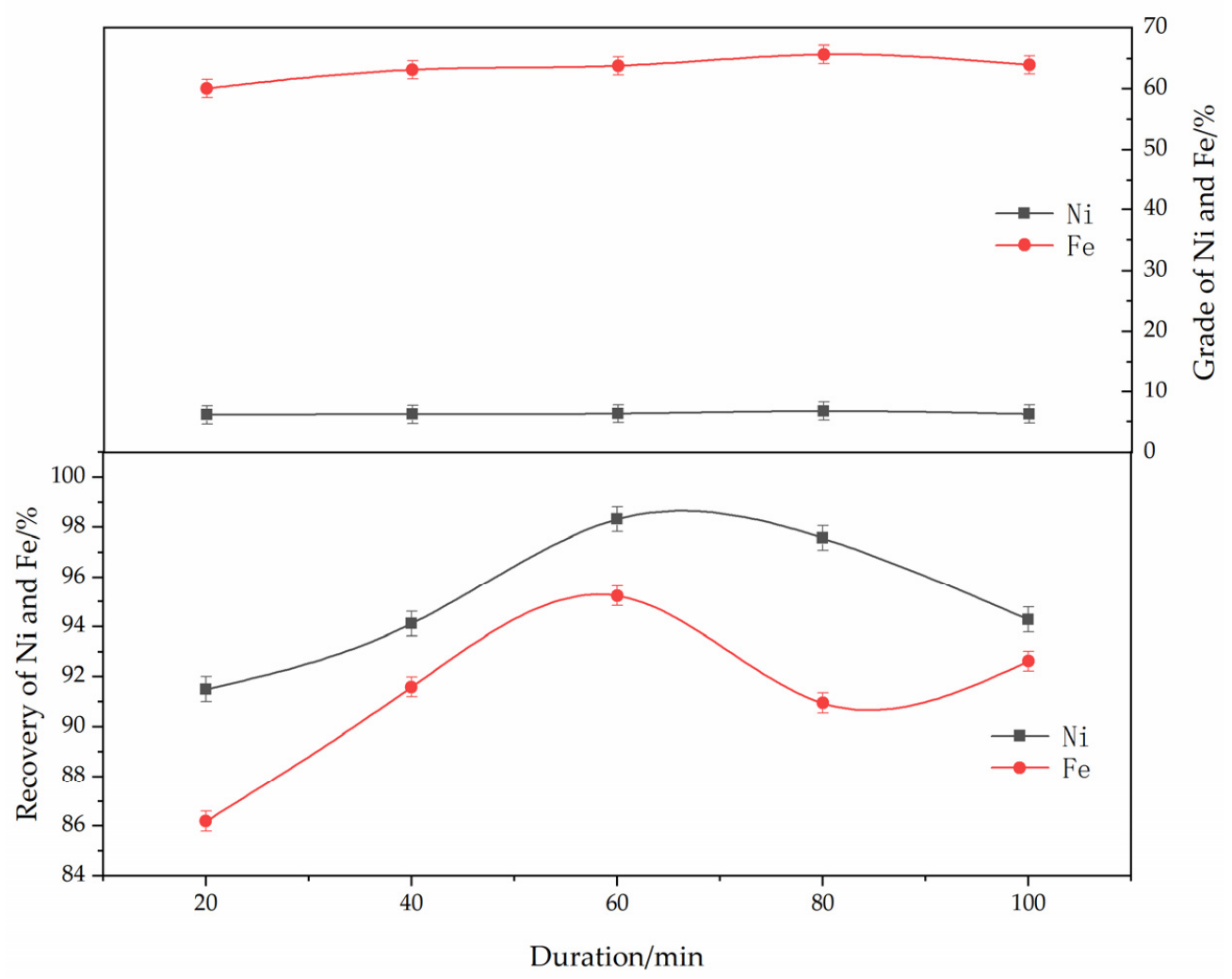

Figure 7. The effect of roasting duration on the grade and recovery of nickel-iron in ferronickel concentrate. (The ferronickel concentrate dosage was $30 \mathrm{wt}$. \%, The reducing temperature was $1250{ }^{\circ} \mathrm{C}$, the reductant dosage was $8 \mathrm{wt}$. \%, the magnetic separation was $150 \mathrm{mT}$ ).

The effect of reductant dosage on the reduction and magnetic separation of low-grade nickel laterite ore is shown in Figure 8. The experimental conditions were determined as follows: ferronickel concentrate dosage of $30 \%$, reduction temperature of $1250{ }^{\circ} \mathrm{C}$, roasting time of $60 \mathrm{~min}$, calcium fluoride content of 7\%, magnetic separation intensity of $150 \mathrm{mT}$. As can be seen from Figure 8, with the increase of reductant dosage, the grade of nickel in ferronickel-concentrate first increased and then decreased, while the grade of iron increased. When reductant dosage increased from $4 \%$ to $10 \%$, the nickel grade increased from $5.66 \%$ to $7.45 \%$, and the recovery efficiency of nickel increased from $67.0 \%$ to $96.3 \%$. However, when the reductant dosage increased to $12 \%$, the grade of the nickel decreased to $6.44 \%$, and the recovery efficiency of nickel was $90.5 \%$. Increasing the reductant dosage can reduce the metal oxides, but excessive residual anthracite will increase the amount of residual carbon, and produce more ash, which leads to the difficulty of migration and aggregation of ferronickel after reduction. Therefore, the smaller ferronickel particles are wrapped by impurities and cannot be separated effectively by magnetic separation. In addition, a large amount of iron oxide becomes reduced to the concentrate. Excessive residual anthracite causes the decrease of the nickel grade in concentrate, therefore the optimum amount of reductant is $8 \%$. 


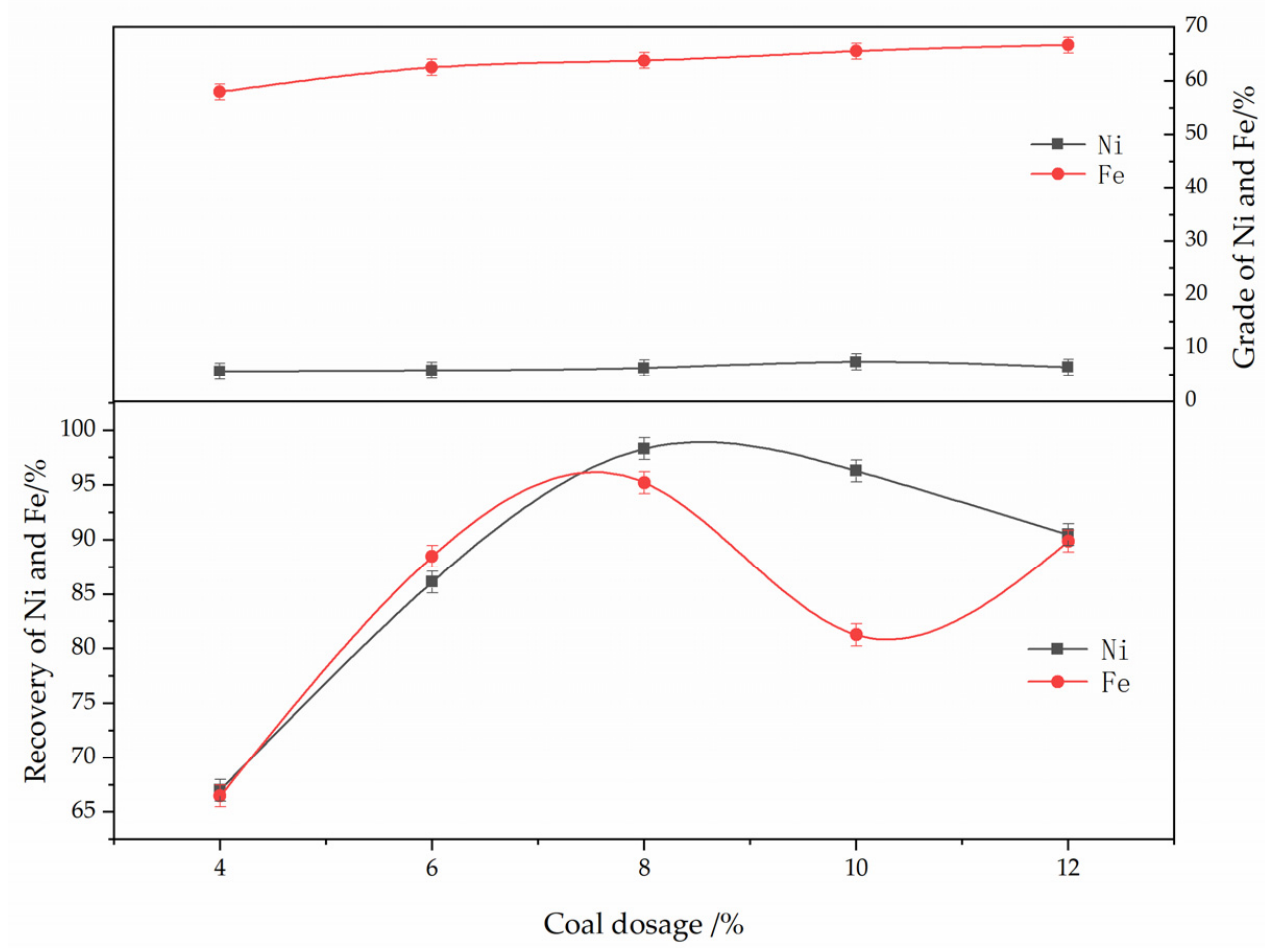

Figure 8. The effect of reductant dosage on the grade and recovery of nickel and iron in ferronickel concentrate. (The ferronickel concentrate dosage was $30 \mathrm{wt}$. \%, The reducing temperature was $1250{ }^{\circ} \mathrm{C}$, the roasting duration was $60 \mathrm{~min}$, the magnetic separation was $150 \mathrm{mT}$ ).

\subsubsection{Effects of Magnetic Separation}

The effect of magnetic separation on the reduction and magnetic separation of lowgrade nickel laterite ore is shown in Figure 9. The experimental conditions were determined as follows: ferronickel concentrate dosage of $30 \%$, reduction temperature of $1250{ }^{\circ} \mathrm{C}$, roasting time of $60 \mathrm{~min}$, reductant dosage of $8 \%$, calcium fluoride content of $7 \%$. As can be seen from Figure 9, with an increase in the magnetic field intensity, the grades of iron and nickel in ferronickel concentrate decreased, but the corresponding recovery efficiency increased. This is because that the different size of nickel-iron particles generated in the roasting process caused different forces of these particles in a magnetic field, thereby affecting the magnetic separation effect. The larger particles were easier to adsorb for the magnetic field. When the magnetic field was weak, the small ferronickel particles and some metallic iron inclusions did not become adsorbed by the magnetic field, meaning that the grades of iron and nickel were higher, but the recovery efficiency was low. With the increase in magnetic field intensity, these weak magnetic materials enter the ferronickel concentrate, which reduces the grades of iron and nickel, but the recovery efficiency of iron and nickel increased. Based on the grades and recovery efficiency of iron and nickel in ferronickel concentrate, magnetic field intensity of $150 \mathrm{mT}$ is optimum condition. 


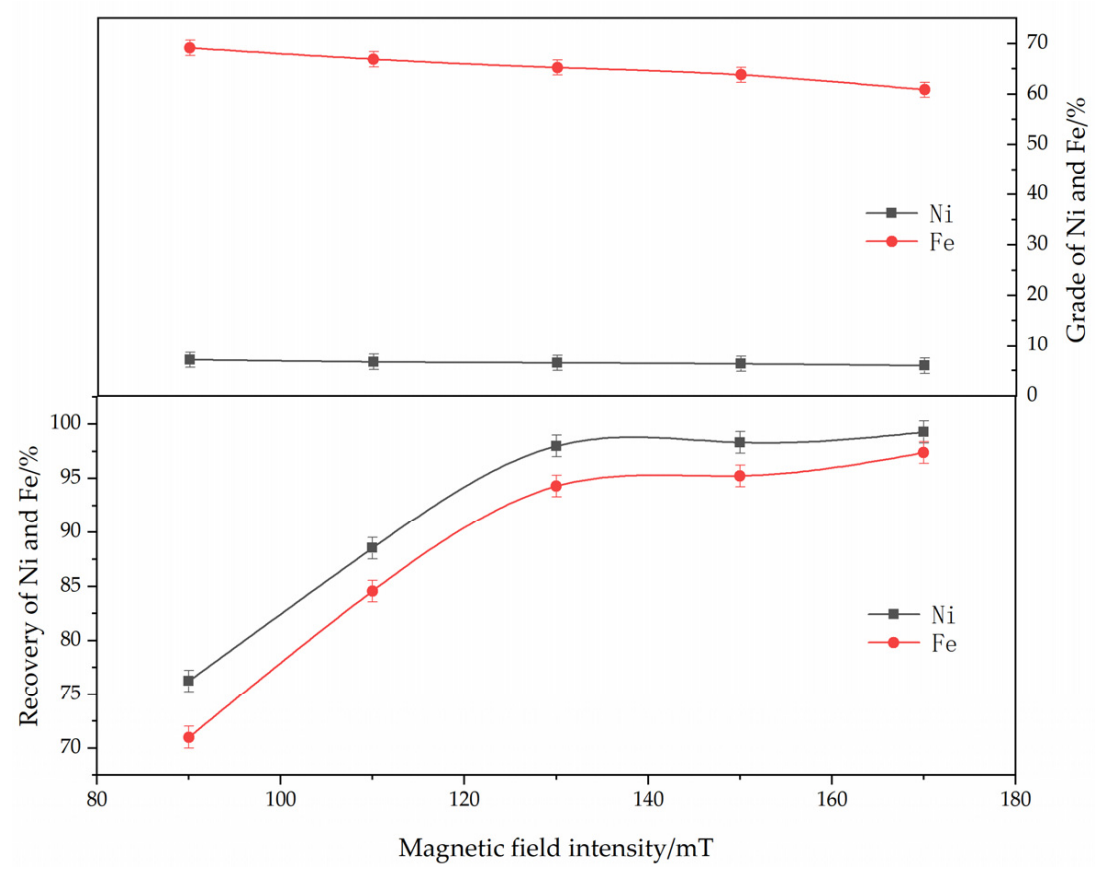

Figure 9. The effect of magnetic separation on the grade and recovery of nickel and iron in ferronickel concentrate. (The ferronickel concentrate dosage was $30 \mathrm{wt}$. \%, The reducing temperature was $1250{ }^{\circ} \mathrm{C}$, the roasting duration was $60 \mathrm{~min}$, the reductant dosage was $8 \mathrm{wt}$. \%).

In conclusion, the optimum technological conditions for preparing high grade ferronickel concentrate, through the addition of ferronickel concentrate using a reduction roasting-magnetic separation method are as follows: concentrate dosage of $30 \%$ and anthracite dosage of $8 \%$, reduction temperature of $1250{ }^{\circ} \mathrm{C}$, roasting time of $60 \mathrm{~min}$, magnetic separation intensity of $150 \mathrm{mT}$. Under these conditions, the grades of nickel and iron in ferronickel concentrate were $8.62 \%$ and $80.1 \%$, and the recovery efficiency of nickel and iron were $98.8 \%$ and $82.4 \%$. Compared with the nickel grade in the raw ore $(\mathrm{Ni}-0.820 \%$, Fe-9.67\%), it is increased by about 10 times and about 8 times compared with the iron grade.

According to a literature review [13-17], when the additive was $\mathrm{Na}_{2} \mathrm{~S}_{2} \mathrm{O}_{3}$ or $\mathrm{S}$, the laterite nickel ore $(1.59 \%$ of $\mathrm{Ni}$ and $42.0 \%$ of $\mathrm{Fe})$ was reduced and melted. It was gotten that $14.3 \% \mathrm{Ni}$ content and $93.2 \%$ recovery, the iron content was $64 \%$ and the recovery was about $19.0 \%$. The grade of nickel increased by 9 times and grade of iron increased by 1.5 times. When the additive is sulfur, it yielded a product with $13.6 \% \mathrm{Ni}$ content and its recovery reaching $97.9 \%$. Additionally, the iron content was $53.4 \%$ and the recovery was around $20 \%$. The grade of nickel increased by 8.5 times and the grade of iron increased by 1.2 times. When the additive was $\mathrm{NaCl}$, laterite ore $(0.820 \%$ of $\mathrm{Ni}$ and $9.67 \%$ of $\mathrm{Fe})$ was reduced and melted. The results indicate that for a ferronickel content of $7.09 \% \mathrm{Ni}, 70 \% \mathrm{Fe}$, a nickel recovery of $98.3 \%$, a Fe recovery of $72.1 \%$. The grade of nickel in-creased by 8.6 times and grade of iron increased by 7.2 times. In this case, the aggregation efficiency and recovery of nickel and iron in this study are higher.

\subsection{Action Mechanisms of Ferronickel Concentrate}

\subsubsection{Polymerization and Growth of Ferronickel Particles}

Figure 10 shows an SEM image of the reduction sample under the action of the promoter $\mathrm{CaF}_{2}$. After adding $\mathrm{CaF}_{2}$, part of the nickel and iron oxides was reduced, and the ferronickel concentrate was distributed in a bright white granular form. The grey area is $\mathrm{FeO}$, and the darker area is forsterite $\left[\mathrm{Mg}_{2} \mathrm{SiO}_{4}\right]$. The study suggested that $\mathrm{CaF}_{2}$, as a promoter, can effectively destroy the mineral lattice which loaded nickel and iron, and reduce the surface tension of the mineral, and promote the metallization and reduction of nickel and iron. Figure 11 shows an SEM image of the reduction sample during the 
addition of ferronickel concentrate. It can be clearly seen from Figure 11 that the nickel-iron solid solution changes from the original granular distribution to the band shape, indicating that the addition of the ferronickel concentrate can significantly promote the accumulation of ferronickel particles. Figure 12 shows an SEM image of the reduction roasting sample after adding $\mathrm{CaF}_{2}$ and the ferronickel concentrate. It can be clearly seen from Figure 12 that there are a large number of bright white-banded solids of nickel and iron, indicating that the combined action of calcium fluoride and ferronickel concentrate can significantly improve the reduction roasting effect. An EDS analysis of the reduction samples shows that the contents of nickel and iron in the ferronickel concentrate phase were higher under the condition of adding ferronickel concentrate, which further indicates that the addition of the ferronickel concentrate can effectively promote the aggregation and growth of ferronickel particles.

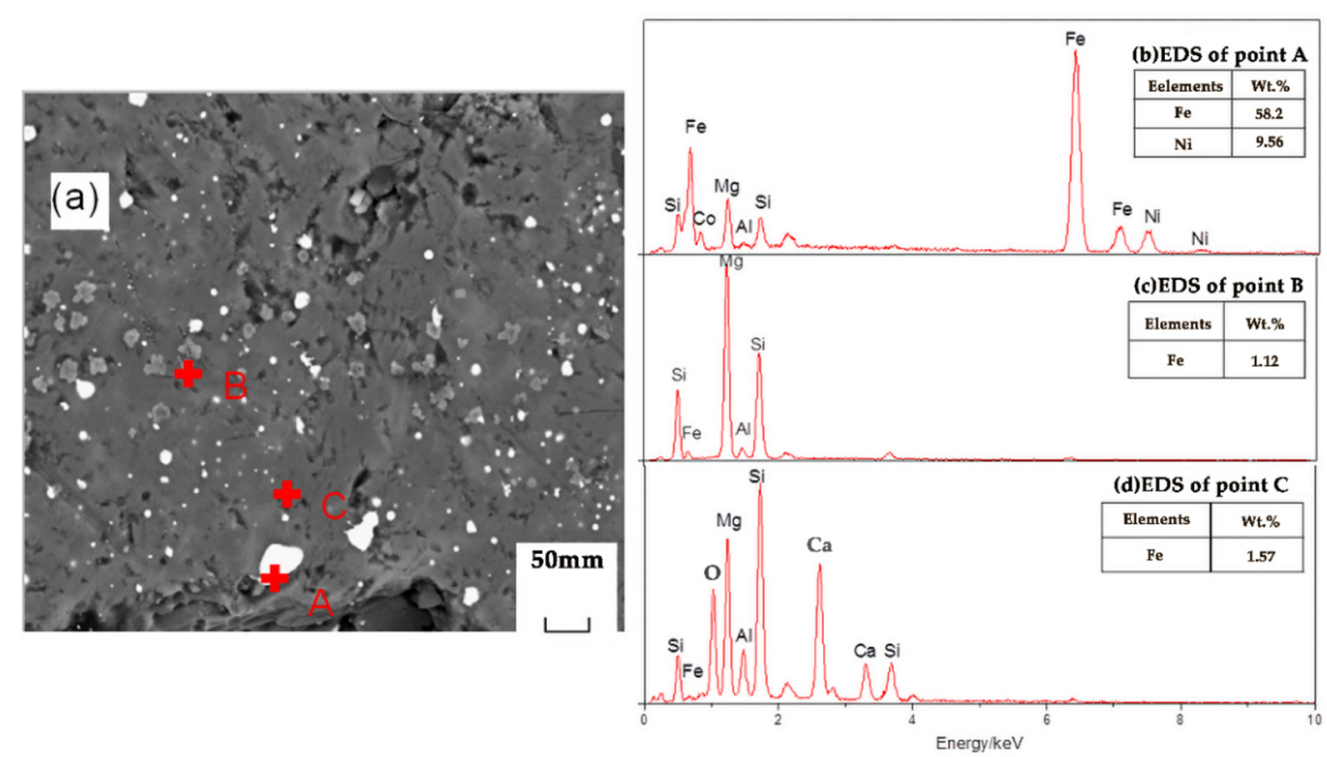

Figure 10. SEM/EDS analysis of reduction samples under the action of calcium fluoride; (a) scanning electron microscope image, (b) EDS spectrum of spot A in image (a), (c) EDS spectrum of spot B in image (a), (d) EDS spectrum of spot $\mathrm{C}$ in image (a).
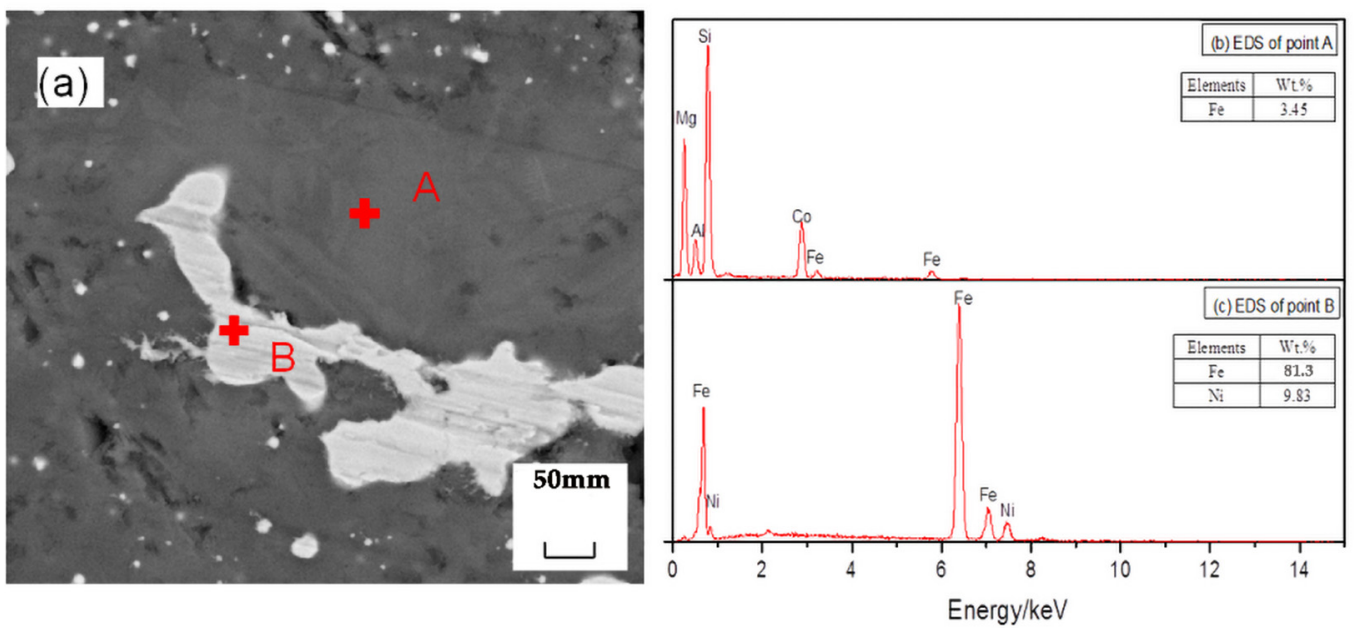

Figure 11. SEM/EDS analysis of reduction samples under the action of ferronickel concentrate; (a) scanning electron microscope image, (b) EDS spectrum of spot A in image (a), (c) EDS spectrum of spot B in image (a). 


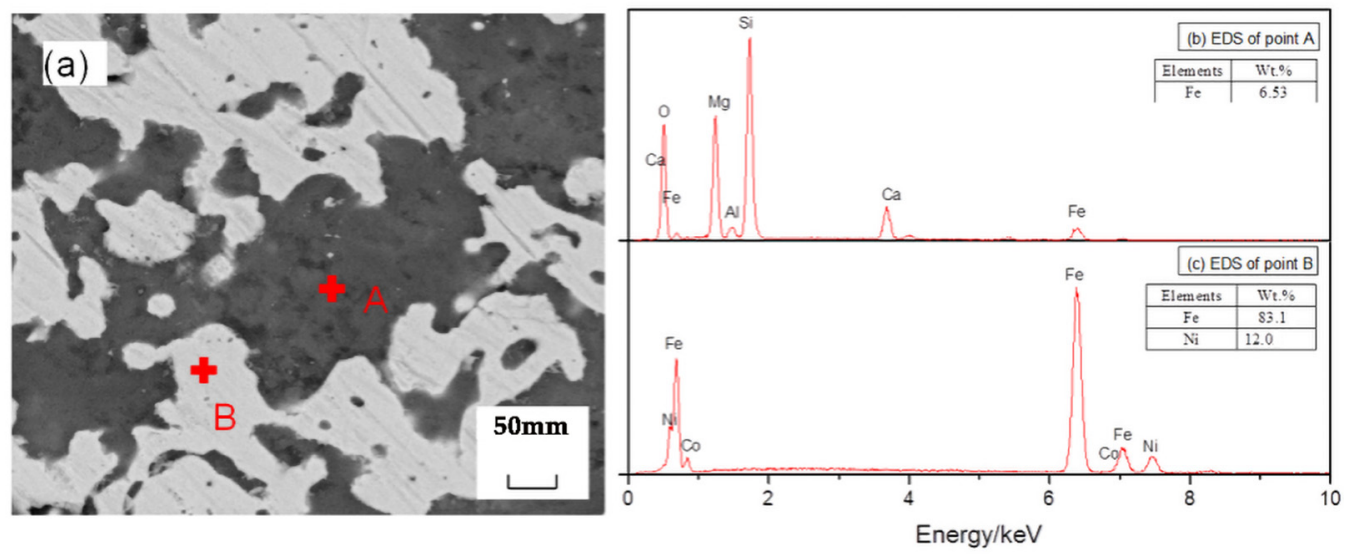

Figure 12. SEM/EDS analysis of reduction samples under the action of calcium fluoride and ferronickel concentrate; (a) scanning electron microscope image, (b) EDS spectrum of spot A in image (a), (c) EDS spectrum of spot B in image (a).

As shown in Figure 12, after $\mathrm{CaF}_{2}$ and ferronickel concentrate were added, nickel and iron became clearly aggregated. Additionally, $\mathrm{CaF}_{2}$ plays an important role. The $\mathrm{CaF}_{2}$ decomposes into $\mathrm{Ca}^{2+}$ and $\mathrm{F}^{-}$at high temperature. $\mathrm{F}^{-}$and $\mathrm{O}^{2-}$ have the same ionic radius. In the reduction process, $\mathrm{F}^{-}$enters into the silicate structure, which is composed of a Si-O tetrahedral structure. Reducing the bond energy of Si-O makes it more susceptible to fracturing at high temperatures, therefore, reducing the melting point of silicate. In the actual reduction process, the $\mathrm{CaF}_{2}$ react complicatedly with the serpentine $\left(\mathrm{Mg}_{3} \mathrm{Si}_{2} \mathrm{O}_{5}(\mathrm{OH})_{4}\right)$ of the gangue phase to form tremolite $\left(\mathrm{Ca}_{\mathrm{x}} \mathrm{Mg}_{\mathrm{y}}\left(\mathrm{Si}_{4} \mathrm{O}_{11}\right)_{2} \mathrm{~F}_{2}, \mathrm{X} \approx 2\right.$; $y \approx 5$ ), which has a low melting point. Then, the decrease of the melting point of the whole reduction system can increase the diffusion coefficient of atoms, accelerate the atomic movement rate between reactants and promote the precipitation of metal particles along the boundary, and the rapid aggregation between particles.

\subsubsection{Migration of Nickel/Iron from Raw Ore to Ferronickel Concentrate}

Figure 13 shows the schematic diagram of a diffusion experiment sample. the first and third layers were raw ore, mixed with anthracite and additives, and the second layer was concentrated. The prepared samples were reduced in a tubular furnace under the reduction conditions for $60 \mathrm{~min}$ at $1250^{\circ} \mathrm{C}$, and the reduction samples were analyzed.

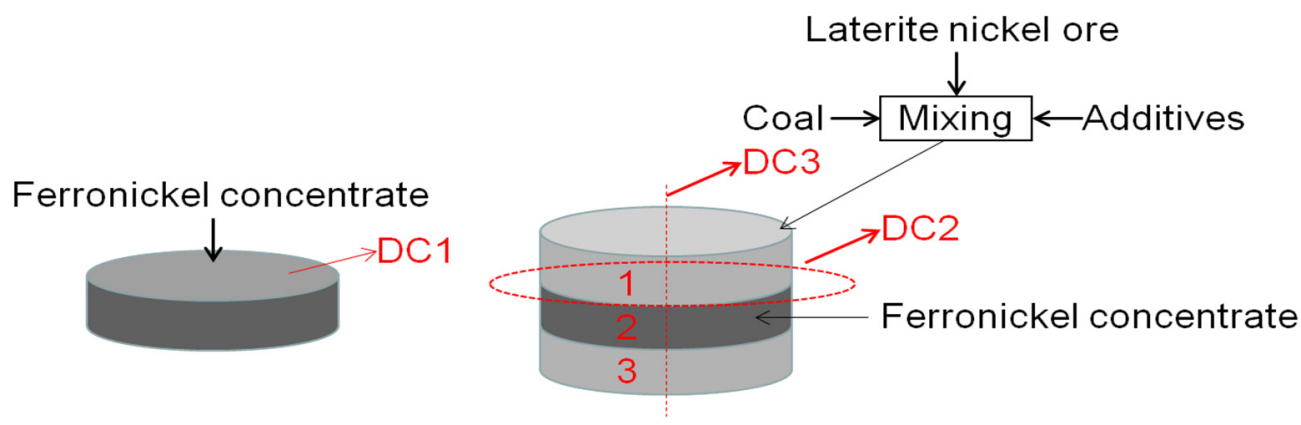

(a)

(b)

Figure 13. Schematic diagram of diffusion experiment sample $(\mathrm{R}=1 \mathrm{~cm})$; $(\mathbf{a})$ Schematic diagram of ferronickel concentrate layer, (b) Schematic diagram of experimental sample. 
Figure 14 shows an SEM of reduced concentrate samples. Figure 14a shows the SEM of the DC1 interface layer on the surface of the reduced concentrate samples. Nickel and iron oxides were reduced and metallized, and the ferronickel were migrated and aggregated, but the effect of aggregation and growth is not obvious. It is difficult to enrich the fine ferronickel phase by magnetic separation. Figure 14b shows an SEM of the DC2 interface layer on the cross section of the contact between raw ore and concentrate. A large number of bright white and light gray particles are visible in Figure 14b. A large number of bright white bands were formed, as illustrated. The new mineral phases were aggregated to the ferronickel phase. The energy spectrum analysis shows that the main phase in the bright white area of the roasted ore was ferronickel alloy, the main phase in the light gray area was spinel, and the main phase in the light black area was mafic olivine. This indicates that the metallic nickel and iron in the ore migrates and enriches the ferronickel concentrate during reduction roasting, and the size of ferronickel particles significantly increased, which effectively promotes the formation of ferronickel alloy.
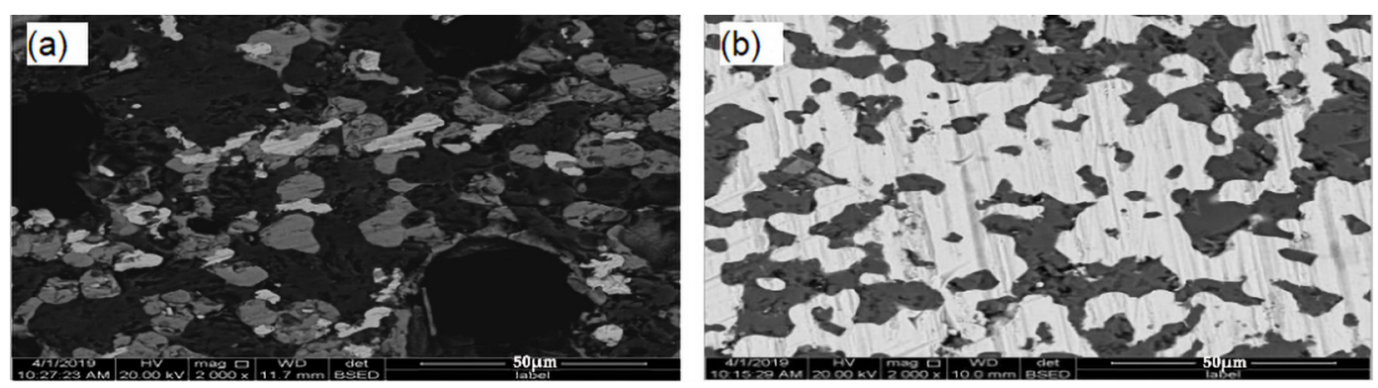

Figure 14. SEM of the cross section of DC1 and DC2; (a) the SEM of the DC1, (b) the SEM of the DC2.

Figure 15 shows the SEM of the cross section of DC3. Figure 16 shows the elemental mapping results of DC3. The enrichment of ferronickel particles in the boundary layer between raw ore and concentrate is evident.
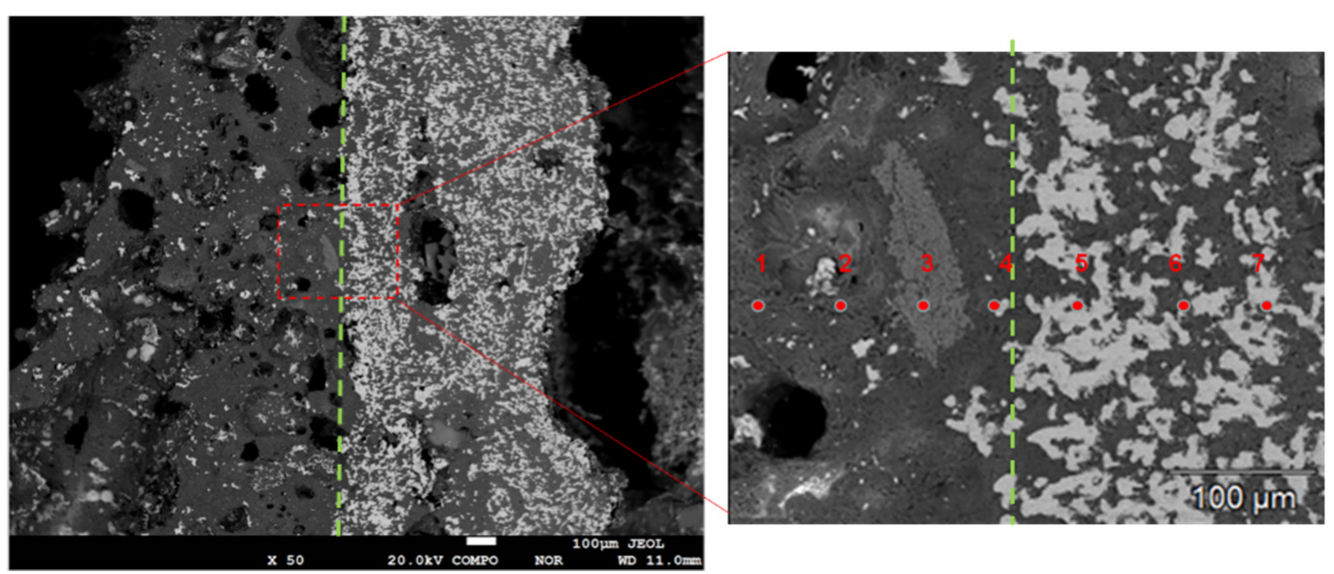

Figure 15. SEM of the cross section of DC3; the green dot line was borderline of raw ore and concentrate.

The Ni and Fe contents along a line of selected points were obtained by electron probe shown in Figure 17. When the points of interest were selected, positions that included high contents of nickel and iron were not considered, because these positions represented the alloy phase area. The results show that the nickel and iron contents are highest near the boundary line, and the further away from the boundary line, the lower the contents of nickel and iron at the selected point line. This result is consistent with the elemental mapping results of DC3. The ferronickel particles in the raw ore diffused and migrated to the side of the ferronickel concentrate in the reaction process. 

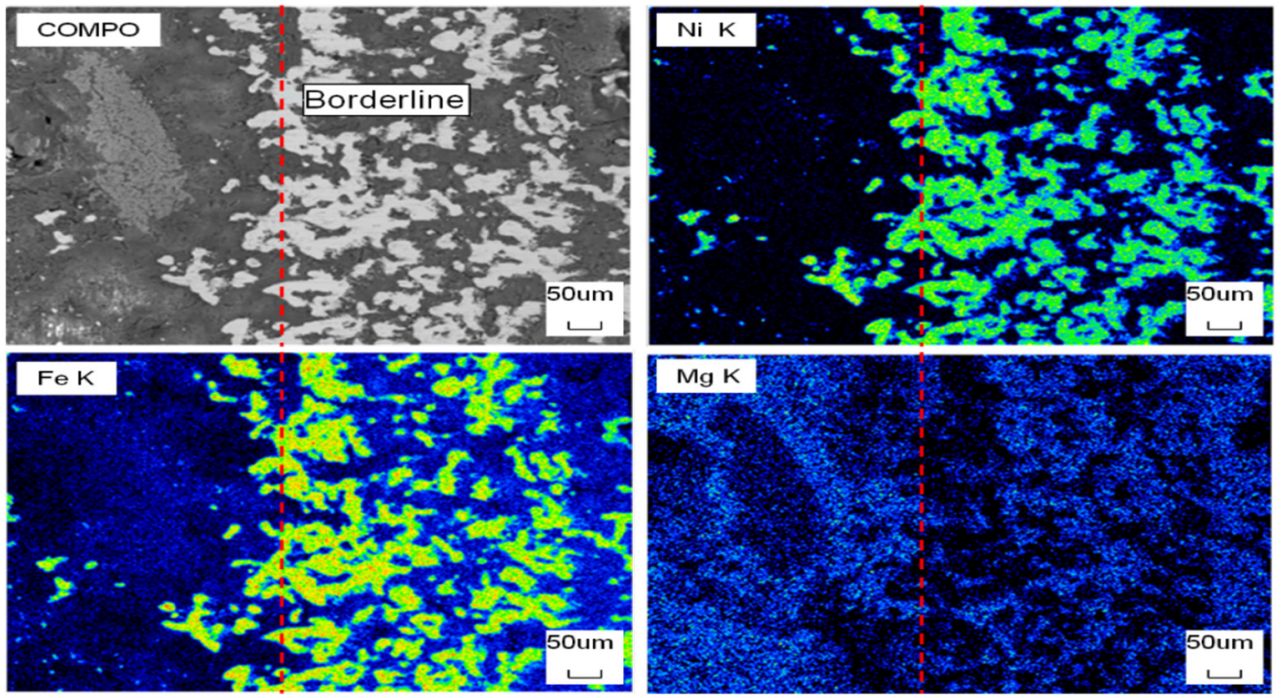

Figure 16. EDS mapping of the cross section of DC3; the red dot line was borderline of raw ore and concentrate.

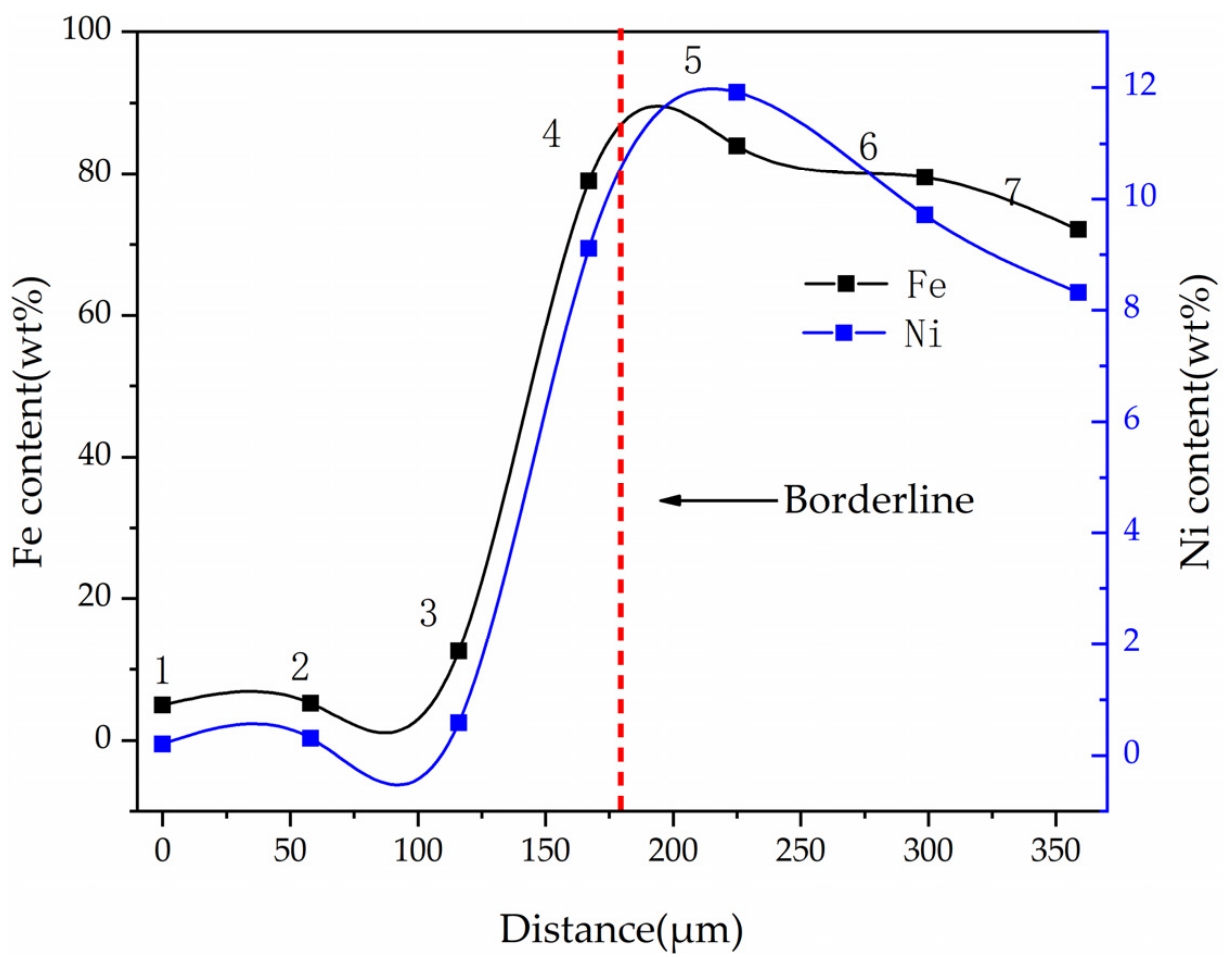

Figure 17. Ni and Fe contents of different points at cross section of DC3.

\section{Conclusions}

In this study, ferronickel concentrate from low-grade laterite nickel ore in Yunnan Province was prepared, and the migration and accumulation behavior of ferronickel particles in the reduction process were studied. The conclusions are as follows:

(1) The ferronickel concentrate, with $8.62 \% \mathrm{Ni}$ and $80.1 \%$ Fe was prepared through reduction roasting at $1250{ }^{\circ} \mathrm{C}$ for $60 \mathrm{~min}$ in the presence of $30 \%$ ferronickel concentrate and $8 \%$ anthracite, followed by $150 \mathrm{mT}$ wet magnetic separation. The corresponding recovery efficiency of $\mathrm{Ni}$ and Fe were $98.8 \%$ and $82.4 \%$, respectively.

(2) Ferronickel concentrate, used as an activating agent, can clearly improve the migration, aggregation and growth of the metal phase in the reduction process of laterite 
nickel ore. The effective separation of the ferronickel alloy from forsterite is achieved, and the grades and recovery efficiency of nickel and iron elements in raw ore are significantly improved.

(3) An SEM and EDS analysis indicated that ferronickel concentrate, acting as an activating agent, enhanced ferronickel-particle growth. The nickel and iron in the ore migrated to the ferronickel concentrate and significantly increased the size of the ferronickel particles to prepare higher grade ferronickel concentrate.

Author Contributions: Conceptualization, B.L. and Y.W. (Yonggang Wei); methodology, B.L.; investigation, Y.W. (Yuanbo Wang) and C.N.; writing-original draft preparation, Y.W. (Yuanbo Wang) and C.N.; writing-review and editing, Y.W. (Yuanbo Wang), C.N. and B.L. All authors have read and agreed to the published version of the manuscript.

Funding: Financial support for this study was supplied from the Yunnan Provincial Key Research and Development Program-International Science and Technology Cooperation Special Project (Project Nos.2018IA055) and the National Natural Science Foundation of China (Project Nos. 52074140).

Conflicts of Interest: The authors declare no conflict of interest.

\section{References}

1. Abdul, F.; Sungging, P.; Ari, M. Analysis the Effect of Charcoal Mass Variation to Ni Content, Sinter Strength and Yield on Sintering Process of Limonitic Laterite Nickel Ore. Key Eng. Mater. 2020, 867, 25-31. [CrossRef]

2. Gao, J.M.; Du, Z.Y.; Ma, S.J.; Cheng, F.Q.; Li, P. High-Efficiency Leaching of Valuable Metals from Saprolite Laterite Ore Using Pickling Waste Liquor for Synthesis of Spinel-Type Ferrites Mfe2o4 with Excellent Magnetic Properties. J. Mater. Res. Technol. 2021, 10, 988-1001. [CrossRef]

3. Jiang, M.; Sun, T.C.; Liu, Z.G.; Kou, J.; Liu, N.; Zhang, S.Y. Mechanism of Sodium Sulfate in Promoting Selective Reduction of Nickel Laterite Ore During Reduction Roasting Process. Int. J. Miner. Process. 2013, 123, 32-38. [CrossRef]

4. Jiang, X.; He, L.; Wang, L.; Xiang, D.W.; An, H.W.; Shen, F.M. Effects of Reducing Parameters on the Size of Ferronickel Particles in the Reduced Laterite Nickel Ores. Metall. Mater. Trans. B-Process Metall. Mater. Process. Sci. 2020, 51, 2653-2662. [CrossRef]

5. Li, B.; Ding, Z.G.; Wei, Y.G.; Wang, H.; Yang, Y.D.; Barati, M. Kinetics of Reduction of Low-Grade Nickel Laterite Ore Using Carbon Monoxide. Metall. Mater. Trans. B 2018, 49, 3067-3073. [CrossRef]

6. Li, G.H.; Shi, T.M.; Rao, M.J.; Jiang, T.; Zhang, Y.B. Beneficiation of Nickeliferous Laterite by Reduction Roasting in the Presence of Sodium Sulfate. Miner. Eng. 2012, 32, 19-26. [CrossRef]

7. Ma, B.Z.; Li, X.; Yang, W.J.; Hu, D.; Xing, P.; Liu, B.; Wang, C.Y. Nonmolten State Metalized Reduction of Saprolitic Laterite Ores: Effective Extraction and Process Optimization of Nickel and Iron. J. Clean. Prod. 2020, 256, 120415. [CrossRef]

8. Pickles, C.A.; Forster, J.; Elliott, R. Thermodynamic Analysis of the Carbothermic Reduction Roasting of a Nickeliferous Limonitic Laterite Ore. Miner. Eng. 2014, 65, 33-40. [CrossRef]

9. Pintowantoro, S.; Widyartha, A.B.; Setiyorini, Y.; Abdul, F. Sodium Thiosulfate and Natural Sulfur: Novel Potential Additives for Selective Reduction of Limonitic Laterite Ore. J. Sustain. Metall. 2021, 7, 481-494. [CrossRef]

10. Kim, J.; Dodbiba, G.; Tanno, H.; Okaya, K.; Matsuo, S.; Fujita, T. Calcination of low-grade laterite for concentration of Ni by magnetic separation. Miner. Eng. 2010, 23, 282-288. [CrossRef]

11. Shofi, A.; Rahmahwati, A.; Nurjaman, F.; Suharno, B. Effect of reduction temperature and sodium-based additives on nickel upgrading process of laterites ores. IOP Conf. Ser. Mater. Sci. Eng. 2019, 541, 012002. [CrossRef]

12. Nurjaman, F.; Rahmahwati, A.; Karimy, M.F.; Hastriana, N.; Shofi, A.; Herlina, U.; Suharno, B.; Ferdian, D. The role of sodiumbased additives on reduction process of nickel lateritic ore. IOP Conf. Ser. Mater. Sci. Eng. 2019, 478, 012001. [CrossRef]

13. Shiau, J.S. Carbothermic Reduction of Low-Grade Laterite-Graphite Composite Pellets. Metall. Res. Technol. 2020, 117, 306. [CrossRef]

14. Suharno, B.; Ramadini, C.; Shaleh, R.H.; Shofi, A.; Nurjaman, F. Effect of Sodium Sulfate and Sodium Chloride in Two-Stage Thermal Upgrading of Low-Grade Nickel Lateritic Ore. IOP Conf. Ser. Mater. Sci. Eng. 2019, 523, 012062. [CrossRef]

15. Rhamdhani, M.A.; Hayes, P.C.; Jak, E. Nickel Laterite Part 1-Microstructure and Phase Characterisations During Reduction Roasting and Leaching. Miner. Process. Extr. Metall. 2013, 118, 129-145. [CrossRef]

16. Santoro, L.; Putzolu, F.; Mondillo, N.; Herrington, R.; Najorka, J.; Boni, M.; Dosbaba, M.; Maczurad, M.; Balassone, G. Quantitative Mineralogical Evaluation of Ni-Co Laterite Ores through Xrpd-Qpa- and Automated Sem-Based Approaches: The Wingellina (Western Australia) Case Study. J. Geochem. Explor. 2021, 223, 1-18. [CrossRef]

17. Valix, M.; Cheung, W.H. Effect of Sulfur on the Mineral Phases of Laterite Ores at High Temperature Reduction. Miner. Eng. 2002, 15, 523-530. [CrossRef]

18. Zhao, D.; Ma, B.Z.; Shi, B.D.; Zhou, Z.G.; Xing, P.; Wang, C.Y. Mineralogical Characterization of Limonitic Laterite from Africa and Its Proposed Processing Route. J. Sustain. Metall. 2020, 6, 491-503. [CrossRef] 
19. Zhou, S.; Wei, Y.; Li, B.; Wang, H.; Ma, B.; Wang, C. Mechanism of Sodium Chloride in Promoting Reduction of High-Magnesium Low-Nickel Oxide Ore. Sci. Rep. 2016, 6, 29061. [CrossRef]

20. Hang, G.; Xue, Z.; Wang, J.; Wu, Y. Mechanism of Calcium Sulphate on the Aggregation and Growth of Ferronickel Particles in the self-Reduction of Saprolitic Nickel Laterite Ore. Metals 2020, 10, 423. [CrossRef]

21. Soner, T.; Kursunoglu, S.; Ichlas, Z.T. Effects of Leaching Parameters on the Dissolution of Nickel, Cobalt, Manganese and Iron from Caldag Lateritic Nickel Ore in Hydrochloric Acid Solution. Can. Metall. Q. 2020, 59, 368-376. [CrossRef]

22. Zhou, S.W.; Wei, Y.G.; Li, B.; Wang, H.; Ma, B.Z.; Wang, C.Y. Chloridization and Reduction Roasting of High-Magnesium Low-Nickel Oxide Ore Followed by Magnetic Separation to Enrich Ferronickel Concentrate. Metall. Mater. Trans. B 2015, 47, 145-153. [CrossRef]

23. Zhu, D.Q.; Cui, Y.; Vining, K.; Hapugoda, S.; Douglas, J.; Pan, J.; Zheng, G.L. Upgrading Low Nickel Content Laterite Ores Using Selective Reduction Followed by Magnetic Separation. Int. J. Miner. Process. 2012, 106, 1-7. [CrossRef] 